\title{
BIVALENT VERB COMPLEMENTS IN ALBANIAN
}

\section{Kadire BINAJ* Ardita BERISHA ${ }^{* *}$}

\begin{abstract}
This research aims at describing and analyzing types of complements in bivalent clauses, namely the internal structure of such clauses and the grammatical patterns of combining the constituents in bivalent clauses. The internal structure of the clause is assigned or determined by the verb, which functions as the central element of the clause. Depending on the type of verb and its combinatorial abilities, certain clause structures or patterns are generated. In this paper we will deal with bivalent verbs, namely the types of complements that complement these verbs in order to create the minimal bivalent clause pattern. First, the complements of these verbs will be dealt with in terms of their syntactic category, i.e. the type of phrase that completes the verb valency. Then, we will proceed with the functional analysis of these complements and in some cases also with the semantic analysis, i.e. the semantic roles that these complements play.
\end{abstract}

Keywords: bivalent clauses, verb types, complement types, adjuncts.

\section{ARNAVUTÇADA BIVALENT FIIILLERIN TÜMLEÇLERİ}

ÖZ: Bu araştırma ile, bivalent cümle tümleçlerinin türlerini tanımlamak ve analiz etmek, yani bu maddelerin içyapısının ve bivalent cümledeki bileşenlerin kombinasyonlarının gramer kalıplarının tanımlanması ve analiz edilmesi amaçlanmaktadır. Cümlenin içyapısı, cümlenin merkezi unsuru olarak görev yapan fiil tarafından tanımlanır veya sınırlandırılır. Fiilin türüne ve kombinatoryal yeteneklerine bağlı olarak, belirli yapılar veya belirli cümle kalıpları oluşturulur. $\mathrm{Bu}$ makalede, bivalent cümle minimal modelini oluşturmak için bu fiilleri tamamlayan tamamlayıc fiiller, yani bivalent tamamlayan fiiller incelenecektir. İlk olarak, bu fiillerin tümleçleri ve sözdizim kategorileri, fiil geçerliliğini tamamlayan cümle türleri bakımından ele alınacaklardır. Çalışmanın devamında ise bu tümleçlerin işlevsel ve bazı durumlarda anlamsal analizine, kısaca bu tümleçlerin oynadığı anlamsal rollerin incelenmesine yer verilecektir.

Anahtar Kelimeler: bivalent cümle, fiil türleri, tümleç türleri, eklem.

\footnotetext{
* Teaching Assist. Department of Albanian Language, at University of Prishtina 'Hasan Prishtina”, E-mail: kadire.binaj@uni-pr.edu. ORCID: https://orcid.org/0000-0002-6711-8033

** Teaching Assist. Department of Albanian Language, at University of Prishtina 'Hasan Prishtina", E-mail: ardita.berisha@uni-pr.edu. ORCID: https://orcid.org/0000-0002-2601-2451 


\section{Introduction}

By the term clause pattern or clause structure we mean the grammatical patterns of combining certain constituents to form different clauses. Clause patterns allow a comprehensive description of the most typical structures of a language, in this case Albanian, which constitute the minimal necessary structural basis of different types of clauses. In this research we will describe and analyze typical structural patterns of clauses with bivalent verbs in Albanian. A clause like Ajo doli ("She left") - has the structure of S (subject) $+\mathrm{V}$ (verb), whereas the clause Ne shikuam një film ("We watched a movie"), has the structure $\mathrm{S}+\mathrm{V}+\mathrm{Od}$. These two types of structures constitute two of the possible clause patterns in Albanian. In the former example, we have a clause pattern with a monovalent verb, whereas the latter case presents a clause pattern with a bivalent verb.

Therefore, clause patterns can be derived by analyzing the internal structure of the clause, namely the verb, which serves as the central element, and its obligatory complements.

In the Encyclopedic Dictionary of Applied Linguistics ${ }^{1}$, it is stated that the term clause pattern is used in the analysis of clause structures, noting the linear ordering of the elements subject + verb + object $+($ object $)$ complement + adjunct, and that languages are categorized based on basic clause patterns or constituent order in a clause. Therefore, clause patterns are also important for language typology. According to the typological classification, Albanian belongs to the SVO language group, like English, French, etc. But unlike French and English, in Albanian this order can change, given that it is a flective language and, as such, has free order. Precisely because of the free order of clause constituents, clause patterns in Albanian are various; however, for practical reasons, when describing Albanian clause patterns, we will rely on the neutral constituent order of the clause. Thus, clauses like: a. U rrëzua Agimi ("Fell Agimi") and b. Agimi u rrëzua ("Agimi fell"), will be presented as having the same clause structure: $\mathrm{S}+\mathrm{V}$, not two.

While there are numerous studies on clause patterns of English and German, see Helbig \& Schenkel ${ }^{2}$; Quirk et al. ${ }^{3}$; Biber et al. ${ }^{4}$; Huddleston \&

\footnotetext{
${ }^{1}$ Keith Johnson, Helen Johnson, Enciclopedic Dictionary of Applied Linguistics: A Handbook for Langugae Teaching, Blackwell Publishing Ltd, Oxford, 1999.

${ }^{2}$ Gerhard Helbig, Wolgang Schenkel, Wörterbuch zur Valenz und Distribution deutscher Verben. VEB Bibliographisches Institut, Leipzig, 1975.

${ }^{3}$ Randolph Quirk et al., A Comprehensive Grammar of the English Language.: Longman, London, 1985.

${ }^{4}$ Douglas Biber et al., Longman Grammar of Spoken and Written English, Pearson Education Limited, Harlow, 1999. 
Pullum $^{5}$; Herbst et al. ${ }^{6}$; Engel \& Schumacher ${ }^{7}$, Engel ${ }^{8}$, Fillmore ${ }^{9}$, the same cannot be said for Albanian. Spiro Floqi ${ }^{10}$ and German scholars Oda Buchholz and Wilfried Fiedler ${ }^{11}$ dealt with this issue in Albanian. Floqi ${ }^{12}$ deals only with the description of simple declarative clauses with finite verbs. He identifies dozens of clause patterns - he describes them according to parts of speech rather than syntactic functions $(\mathrm{S}+\mathrm{V}+\mathrm{O})$ that these elements have in a clause. $\mathrm{He}$ does not deal with cases of subordinate clauses, which, like other constituents, can be verb complements. Floqi makes formal descriptions of clause patterns. As such, the description gives more details about certain patterns, but, on the other hand, formal description, unlike the functional one, increases the number of clause patterns and, consequently, Floyd fails to present what are the most typical clause patterns in Albanian. Unlike Floqi, Buchholz and Fiedler ${ }^{13}$ identify 115 clause patterns in Albanian, which they group into four basic patterns. They start their analysis of clause patterns with the verb functioning as predicate, which they say is the syntactic-structural center of the clause ${ }^{14}$. In these patterns they also include subordinate clauses as part of verb valency. These patterns, however, do not include passive clauses or subject and object omission.

\section{Classification of verbs according to valency}

The clause pattern or the internal structure of the clause is defined or determined by the verb which serves as the central element of the clause. Depending on the type of verb and its combinatorial abilities, different clause structures or patterns are generated. The combinatorial ability of the verb is otherwise known as the verb valency. According to Tesnière ${ }^{15}$, who established the valency concept in linguistics, valency refers to the number of potential actants that complement the verb. Thus, the need that verbs express

${ }^{5}$ Rodney Huddleston, Geoffrey Pullum , The Cambridge Grammar of the English Language, CUP, Cambridge, 2002.

${ }^{6}$ Thomas Herbst et al., A Valency Dictionary of English. Mouton de Gruyter (formerly Mouton, The Hague), Division of Walter de Gruyter GmbH \& Co. KG, Berlin, 2004.

${ }^{7}$ Ulrich Engel, H. Schumacher, Kleines Valenzlekion deutscher Verben.: Narr, Tübingen, 1976.

${ }^{8}$ Ulrich Engel, Deutsche Grammatik. München: IUDICIUM / Groos, 2004/ 1994.

${ }_{9}$ Charles Fillmore, 'The case for case', in: E. Bach and R.T. Harms (eds.) Universals in linguistic theory, Holt, Rinehart and Winston, New York, 1968, pp. 1-88.

${ }^{10}$ Spiro Floqi, Rreth modeleve të fjalisë në shqipen e sotme letrare. Në: SF 4. ASHRPSH, Tiranë, 1978, pp. 25- 51.

11 Oda Buchholz, Wilfried Fiedler, Albanische Grammatik, Verlag Enzyklopädie, Leipzig, 1987.

${ }^{12}$ S. Floqi, op, cit., pp. 30-41.

${ }^{13}$ O. Buchholz, W. Fiedler, op, cit., pp. $472-497$.

${ }^{14}$ O. Buchholz, W. Fiedler., ibid., p. 428.

${ }^{15}$ Lucien Tesnière, Eléments de Syntaxe Structurale, Klincksieck, Paris, 1959, p. 106. 
to be semantically and structurally complemented by adjacent words or constituents is called valency ${ }^{16}$. Depending on the number of actants that accompany a verb to form the minimal clause structure, Lucien Tesnière ${ }^{17}$ distinguishes four types of verbs: avalent, monovalent, bivalent, and trivalent verbs.

Based on Tesnière's model of classifying verbs according to valency, Thoma Dhima ${ }^{18}$ attempts to classify Albanian verbs according to valency by summarizing also the categories of complements by which these verbs are complemented. Consequently, he ${ }^{19}$ also distinguishes four verb classes for Albanian:

- Avalent verbs are accompanied by zero complements. Such verbs denote atmospheric phenomena, such as: bubullin ("thunder"), vetëtin ("lightning"), bën ftohtë ("is cold"), etc.

- Monovalent verbs are accompanied by one complement only, as is the case with the following verbs: ecën ("walks"), hyj ("enter"), ndodh ("happens"), ngjan ("occurs"), etc.

- Bivalent verbs are accompanied by two complements, as is the case with the following verbs: dua ("want"), takoj ("meet"), banon ("resides"), etc.

- Trivalent verbs are accompanied by three complements, as is the case with the following verbs: jap ("give"), them ("say"), vë ("put"), lë ("leave"), etc.

Elements or constituents that "fill" the verb valency, i.e. those that are obligatory to be used together with the verb in order to form a grammatical clause, Tesnière calls actants (actants are also known as: arguments, nuclear elements, or complements). Of course, other optional elements, which Tesnière calls circonstants - circumstants (optional elements are also known as adjuncts) may appear along with the verb. In this paper we will use the terms complement and adjunct.

\section{Differences between complements and adjuncts}

In Tesnierè's grammar Éléments de syntaxe structurale ${ }^{20}$, the traditional principle of the binary divide of the clause into subject (or NP) and predicate

\footnotetext{
${ }^{16}$ Flora Koleci, Giuseppina Turano, Hyrje në sintaksën gjenerative të shqipes, SHBLU, Tiranë, 2011, p. 33.

${ }^{17}$ L. Tesniere, op, cit., p. 106.

${ }^{18}$ Thoma Dhima, Mbi klasifikimin e foljeve sipas valencës. In: Gjuha shqipe 1-2. IAP (67-74) Prishtinë, 2002, pp. $67-74$.

19 Th. Dhima, ibid., p. 70.

${ }^{20}$ L. Tesnière, $o p$, cit.

Trakya Üniversitesi Edebiyat Fakültesi Dergisi, Cilt: 10 Sayl: 19, Ocak 2020, s. 226-241
} 
(or VP), is replaced by the principle of verb centricity that establishes a functional three- partite division of the clause:

- Verbal valency carrier;

- actants (complements);

- circonstants/adjuncts.

In this three- partite clause division, one of the most complex issues is to distinguish or to draw boundaries between complements and adjuncts. Different researchers have proposed different tests to distinguish complements from adjuncts. Reinchardt ${ }^{21}$ groups these tests into four types: 1. Permutation test; 2. Substitution test; 3. Omission test, and 4. Question test. Huddleston and Pullum ${ }^{22}$ give some distinguishing features between complements and adjuncts: the distinctive features a - e relate to syntactic differences, whereas the $\mathrm{f}-\mathrm{h}$ features relate to semantic issues.

In the case of Albanian, one of the most easily applicable tests in distinguishing complements from adjuncts appears to be the omission test. Thus, by omitting or deleting constituents that are not necessary to have a complete semantic and structural clause, the minimal structure of a clause is achieved, that is, the verb with its obligatory complements, e.g.:

Mbrëmë e shikova filmin e ri të Tarantinos në kinemanë e qytetit bashkë me shoqen time.

("Last night I watched Tarantino's new movie in the city cinema with my friend.")

In the above clause the underlined phrases are adjuncts, as a result they can be omitted and the clause still remains grammatical. In this case, the valency carrier, the verb shikoj ("watch") is a bivalent verb, that is, it needs two complements to form a clause. The type of verb determines the type of complement. Given that the verb shikoj ("watch") is a transitive verb, it needs an internal complement, a direct object. The verb in this case determines the function of the complement (direct object) and the syntactic category of the complement: NP in accusative case, because the transitive verb assigns the accusative case to the internal complement, with which it forms the VP. In addition to the internal complement, the bivalent transitive verb is also complemented by the subject, as an external complement of VP. In the given case, the subject is not phonetically expressed, and there is no need to be so, since in the pro-drop languages, like Albanian, the subject is inferred from the

${ }^{21}$ Renate Reichardt, Valency Sentence Patterns and Meaning Interpretation, University of Birmingham, 2013, p. 142.

${ }^{22}$ R. Huddleston, G. Pullum, op, cit., p. 219. 
inflection of the verb shikova ("watched"). The inflection of the verb indicates that the subject is in the first person singular. In addition to the syntactic category, the verb as the clause predicate also assigns semantic roles to its complements, namely arguments (the verb complements which are assigned semantic roles are known as arguments. According to Theta Role Theory, see Carnie $^{23}$, only arguments can be assigned semantic roles). The verb shikoj ("watch") first assigns the semantic role of the theme ${ }^{24}$ to its internal complement, then the verb together with its complement, which constitute the verb phrase, assign the semantic role to the external complement, the subject. In this example, the subject performs the role of the agent/doer ${ }^{25}$.

Not all complements are obligatory (Allerton ${ }^{26}$; Herbst et al. ${ }^{27}$; Storrer $^{28}$ etc). At this point we should distinguish among: a) obligatory complements, b) optional complements, and c) adjuncts.

a. Arta bleu një çantë. ("Arta bought a bag.")

b.1. Arta lexon (libra, revista). (“Arta reads (books, magazines).")



c. Arta erdhi me makinë. ("Arta came by car.")

In the first case (a), the direct object is an obligatory complement. It is licensed by the verb valency, and if this complement is to be omitted, the clause will not be grammatically or semantically correct because the valency assigned by the verb is not filled.

In case (b) the direct objects are verb complements; they fill its valency, and the syntactic category is assigned by the features of the verb. But, unlike the example in (a), the complements in (b) are optional. Optional complements in certain circumstances need not be expressed, and yet the clause is grammatical. Circumstances under which complements may be left unexpressed may be context-dependent or context-independent (Fischer ${ }^{29}$;

\footnotetext{
${ }^{23}$ Andrew Carnie, Syntax: A Generative Introduction, Blackwell Publishing, 2012, p. 221.

${ }^{24}$ A. Carnie (2012: 231): Entities that undergo actions or are moved, experienced, or perceived are called themes.

${ }^{25}$ A Carnie (2012: 229): The initiator or doer of an action is called the agent.

${ }^{26}$ D. J. Allerton, Valency and the English verb, Academic Press, London 1982.

${ }^{27}$ Th. Herbst et al. op. cit.

${ }^{28}$ Angelika Storrer, 'Ergänzungen und Angaben' in Ágel, V., Eichinger, H.-W., Eroms, P.H., Heringer, H.J., Lobin, H. (eds) Dependenz und Valenz / Dependency and Valency Volume 1, Berlin: de Gruyter, 2003, pp. 764- 780.

${ }^{29}$ Klaus Fischer, German - English Verb Valency. Gunter Narr Verlang Tübigen, 1997, p. 46. 
Nikula $^{30}$; Helbig ${ }^{31}$ ). We can see this from the two examples given in (b). In the clause in (b.1.) the optional complement is context-dependent (cotext) - in this case, even though this complement is unexpressed, the clause is grammatical because the complement is known based on the context. On the other hand, in the clause in (b.2.) the unexpressed complement is neither phonetically expressed in the given clause, nor is it mentioned earlier in the text. In this case, the complement is understood by the verb itself - the unexpressed complement is very closely related to the meaning of the verb. So, as in the example in b.2, every time someone talks about one who drinks, it means drinks alcohol, not drinks water, coffee etc. So, the verb pi ("drink") can take various internal complements, such as drink water, coffee, soda, etc., but only in the case of drink alcohol, the complement can create contextindependent ellipsis. In other cases (drink coffee, water, etc.), the complement is either phonetically expressed in the given clause, or mentioned elsewhere in the context (context-dependent ellipsis).

\section{Types of complements in clauses with bivalent verbs}

In order to extract all types of complements in bivalent clauses, a corpus of 6000 words was chosen, wherein all clauses with bivalent verbs were analyzed. The analyzed corpus is literary text ${ }^{32}$, and as such gives a sample of the use of these clauses in literary texts. The analysis of the complements of bivalent verbs was done based on three different criteria: a. classification of complements according to functional criterion; b) classification of complements according to syntactic categories; and c) classification of complements according to thematic roles.

\section{a. Classification of complements of bivalent verbs according to functional criterion}

In the analyzed corpus, all examples of bivalent verbs were extracted, which were first classified according to the functional criterion of clause constituents, specifically according to the function that verb complements play in a clause. By presenting clause structures according to the functions that verb complements play in a clause, we are able to summarize typical structures with bivalent verbs. Then (under 4.2), the syntactic categories by

\footnotetext{
${ }^{30}$ H. Nikula, Verbvalenz - Untersuchungen am Beispiel des deutschen Verbs mit einer kontrastiven Analyse Deutsch - Schwedisch, Acta Univeritatis Upsaliensis, Uppsala, 1976, p. 15.

${ }^{31}$ G. Helbig, Probleme der Valenz- und Kasustheorie. Max Niemeyer, Tübingen, 1992, p. 106. 32 Zejnullah Rrahmani, Pesë vakte, Faik Konica, Prishtina, 2013 and Bekim Fehmiu, Shkëlqim dhe tmerr, KOHA, Prishtina, 2016. 
which these basic bivalent clause structures are realized will be given. Based on the analyzed corpus we have extracted the following structures:

\section{Structure}

1. $\mathrm{S}-\mathrm{V}-\mathrm{O}^{\mathrm{d}}$ :

\section{Example}

Dashi i moçëm e tundi kokën. ("The old ram shook its head.")

2. $\mathrm{S}-\mathrm{V}-\mathrm{Oi}$ :

Një ujk i uritur iu vërsul vathes së fukarasë. ("A hungry wolf rushed into the barn of the poor man.")

3. $\mathrm{S}-\mathrm{V}-\mathrm{PP}^{33}$ : Njerëzit merren me gjithfarë punësh. ("People deal with all kinds of work.")

4. $\mathrm{S}-\mathrm{V}-$ Subjective predicative: Shtëpitë janë njëkatëshe. ("The houses are one-story.")

5. $\mathrm{S}-\mathrm{V}-$ Obligatory adverbial: Ne jetojmë në Gjakovë. ("We live in Gjakova")

Structure 1 represents bivalent clauses with transitive verbs. The transitive verb is first complemented by the internal complement, namely the direct object, which is an obligatory complement of the transitive verb, and then it is further complemented by the external complement functioning as subject. Albanian, just like Italian and Spanish, is part of the pro-drop language group. In Albanian subject is often not phonetically expressed, especially when referring to the first and second person. Although it is dropped or not phonetically expressed, it is clearly marked by the inflection of the verb; therefore, it is not necessary to express it via a pronoun, e.g.: takoja njerëz të tjerë ("__ met other people"). In cases where it refers to a third person, the subject may be missing whenever it is inferred from the preceding context: Agroni erdhi dje. met with everyone."). u takua me të giithë ("Agron came yesterday.

In Structure 2 the verb is complemented by an indirect object in the dative case and by the subject as an external complement. The verb in this case is intransitive. If in this case we had a transitive verb instead, in addition to the indirect object, the verb would be complemented by the direct object, and thus become a trivalent verb that needs three complements (subject, direct object, and indirect object) to form a complete structural and semantic clause.

In Structure 3 the verb is complemented by a prepositional phrase which in this case is an obligatory complement. Only by applying the omission criterion is it understood that in this case we are dealing with a complement, 
not an adjunct. If this phrase were omitted, the remainder would not be a complete structural and semantic clause because the verb valency would not be saturated. The verb is bivalent, which means that the prepositional phrase is part of the verbal valency. This prepositional phrase in Albanian studies has been treated as an indirect object with preposition ${ }^{34}$. In English, Huddleston and Pullum ${ }^{35}$ argue that PPs cannot function as an object, and therefore, in such relations with the verb, they ${ }^{36}$ treat prepositional phrases as non-core complements.

In Structure 4 the verb is a copular, intransitive verb. As such it is complemented by a predicative complement and refers to the subject. Thus, the copular verb is complemented by a subjective predicative complement and by the subject. The subjective predicative complement can be realized by various types of phrases, which we will address under item 4.2. The copular verb, except where it is complemented by a subjective predicative, can also be complemented by an objective predicative. In such cases the verb is complextransitive, and as such it is trivalent; we have not dealt with examples of such cases, since our paper is concerned only with bivalent verb complement.

Lastly, in Structure 5 the verb is again bivalent: its valency is saturated by the subject and the obligatory adjunct. Adjuncts were usually considered as optional elements, different from objects. But, depending on the verb features, adjuncts can also function as verb complements. For example, in the case $\mathrm{Ne}$ jetojmë në Prishtinë ("We live in Prishtina"), the PP saturates the verbal valency; therefore, it is obligatory to the clause structure. On the contrary, in the case: Unë e takova Artën në Prishtinë ("I met Arta in Prishtina") we are dealing with an adjunct because the verb is bivalent. The verb takova ("met") in addition to the number of complements, also determines their type: direct object and subject. Since verb valency is saturated, the adjunct is an optional element in the clause: it is not assigned by the verb valency and thus can be omitted without ruining the clause structure.

Based on the examples in Structure 3 and Structure 5 above, it can be seen that both prepositional phrases and in some cases adverbial phrases can be complements of verbal valency, although they are not assigned the case by the verb, that is, their form is not determined by the verb which serves as valency carrier. Regardless of the fact that their form is not determined by the verb, they are semantically necessary for the verb. The verb banon ("resides")

${ }^{34}$ ASHSH, Gramatika e gjuhës shqipe I dhe II, IGJL, Tiranë, 2002.

${ }^{35}$ R. Huddleston, G. Pullum, op, cit.

${ }^{36}$ R. Huddleston, G. Pullum, ibid. 
requires that there be a complement indicating location. And, in this case, such complement is realized by a PP whose semantics denotes spatial location.

\section{b. Classification of complements according to syntactic categories}

The five structures specified above present the most basic structures of clauses with bivalent verbs. This general representation is provided by grouping all clauses according to the functional criterion. However, each of the above structures can be expressed by different syntactic categories. Below we will present all the syntactic categories by which the complements of the five basic structures shown above are expressed.

\section{Pattern I}

1. $S-V-O^{d}$ :

Dashi i moçëm e tundi kokën.

("The old ram shook its head")

The first pattern is realized by the following syntactic categories:
1.1. $\mathrm{NP}-$ transitive verb - NP:
Ajo i lëshoi do klithma të egra.

1.2. pro - transitive verb $-\mathrm{NP}$ :

("She unleashed wild cries")

I njoh disa prej tyre.

("I know some of them")

1.3. $\mathrm{NP}-$ transitive verb - $\mathrm{CP}$ (subordinate clause):

Ai e di sa shkurtohet e sa zgjatet koha e lindjes së secilit.

("He knows by how much the wombs fall short or exceed")

1.4. pro - transitive verb - CP:

E kuptoja që shumica prej tyre flisnin në të njëjtën gjuhë.

("I realized that most of them spoke the same language.")

The first pattern consisting of a transitive verb, the direct object and the subject, in the analyzed corpus was realized through the four above variants $(1.1-1.4)$. The verbs of the first two clauses: lëshoj ("unleash") and njoh ("know") realize their direct objects by noun phrases, which means that verbs also assign the syntactic category of their complement. Verbs in 1.3. and 1.4, $d i$ ("know") and kuptoj ("realize") have the ability to be complemented by two different syntactic categories, namely $\mathrm{CP}$, as presented in the examples given, but also with NP, for example: Ai e di këtë gjë ("He knows this.") - So, in the last two cases, the verbs can realize their direct objects either by an NP or by a CP, whereas in the first two cases direct objects can only be realized by NPs.

\section{Pattern II}

2. S-V - Oi: Një ujk i uritur iu vërsul vathes së fukarasë. ("A hungry wolf rushed into the barn of the poor man.") 
The second pattern has as valency carrier an intransitive verb which is complemented by the indirect object and the subject. We encountered this pattern much less frequently in the analyzed corpus.

$\mathrm{S}-\mathrm{V}-\mathrm{Oi}$ pattern is realized by the following syntactic categories:

2.1. NP - intransitive verb - NP:

Një ujk iu vërsul vathës së fukarasë. / Atyre u erdhi dënimi.

("A hungry wolf rushed into the barn of the poor man.") / ("Punishment came upon them.")

2.2. pro - intransitive verb - NP:

I ngjajnë asaj kundërvënies së fuqishme muzikore midis basit dhe sopranos.

("They resemble that powerful musical contrast between bass and soprano.")

This model is realized only by these two variants. In version 2.2 the subject is not phonetically expressed in the given clause because the same is mentioned in the preceding clause. Thus, the reference is inferred from the context while its grammatical marking is done through the verbal inflection (third person plural).

\section{Pattern III}

3. $\mathrm{S}-\mathrm{V}-\mathrm{PP}$ :

Njerëzit merren me gjithfarë punësh.

("People deal with all kinds of work.")

In the third pattern the verb that serves as valency carrier is an intransitive verb which is complemented by the subject as an external complement and the prepositional phrase functioning as indirect object with preposition. In such cases, as we have stated above, prepositional phrases are obligatory for the saturation of verbal valency. Unlike pattern I, in which the transitive verb assigns the accusative case to the NP to function as a direct object, and unlike pattern II in which the verb assigns the dative case to the NP to function as an indirect object, in pattern III the verb does not determine the form of the internal complement; therefore, it cannot assign case to the prepositional phrase. Although the form of the PP is not determined by the verb, it is still a complement of the verb and not an adjunct. The status of PPs as complements in such cases can be justified by the fact that they are obligatory elements of the verb valency and that their semantic relation to the verb is so close that without them the verb cannot form grammatical clauses.

Pattern 3 in the given corpus is realized only by the following syntactic categories: 
3.1. NP - intransitive verb - PP: Njerëzit merren me gjithfarë punësh.

("People deal with all kinds of work.")

Njeriu përbëhet prej përvojave të secilit moment. ("Man is the sum of the experiences of each moment")

Ato lidhen me jetën njerëzore.

\section{Pattern IV}

("They relate to human life")

4. S-V - Subjective predicative complement: Shtëpitë janë njëkatëshe.

("The houses are one-story.")

In the fourth model the verb is a copular verb. Since it is semantically empty, it is complemented by a predicative complement and the subject. This clause pattern in the analyzed corpus is realized by the following syntactic categories:

4.1. NP - copular verb - NP:

4.2. $\mathrm{NP}$ - copular verb - AdjP:

4.3. $\mathrm{NP}-$ copular verb $-\mathrm{PP}$ :

Ditët e fundit të dimrit kanë qenë me një mot të bukur.

("The last days of winter were nice weather days.")

4.4. NP - copular verb - AdvP:

Gjërat nuk janë ashtu.

("Things are not like that")

4.5. $\mathrm{NP}$ - resultative verb - PP/AdjP:

Uji i lumit kish përfunduar në pisllëk.

("The river water had ended in the dirt.")

As can be seen from the examples above, the subjective predicative complement in Albanian can be realized by various syntactic categories: NP, AdjP, PP, and AdvP. The verb may be a verb indicating state or it may be a resultative verb.

\section{Pattern V}

5. $\mathrm{S}-\mathrm{V}-$ obligatory adverbial:

Ne jetojmë në Gjakovë.

("We live in Gjakova.")

In the fifth pattern, as in the third pattern, the verb does not determine the form of the internal complement. The adjunct in such cases is an obligatory 
element of verb valency. The complements of the fifth clause pattern with bivalent verbs are realized by the following syntactic categories:

5.1. $\mathrm{S}$ - verb denoting motion - PP/ AdvP:

Ne hymë në klasë. Ne shkuam atje.

("We entered class. We went there.")

5.2. $\mathrm{S}-$ state verb - AdvP/PP:

Ne nuk jemi aty. Kopshti me perime gjendet nga ana e djathtë.

("We are not there. The vegetable garden is on the right.")

Such clauses prove that even the adjuncts are in some cases obligatory. They are very closely related to the verb semantics and are therefore part of verbal valency. The semantics of such verbs require that the internal complement indicate spatial location, direction of motion, etc., and without this complement, the verb cannot form grammatical clauses because its valency is not saturated. Even if such complements are absent or not phonetically expressed, they are implied by the semantics of the verb eg: ne hymë_ ("we entered__ although it may not have the phonetically expressed complement, the verb is understood to be an elliptical phrase that indicates location: we entered somewhere: in the class / at home / the school etc.

\subsection{Classification of complements according to thematic roles}

The internal structure of the clause can also be described and analyzed in terms of the semantic relation, namely the thematic roles that the arguments carry. According to the thematic role theory, clause constituents are the predicate and its arguments. According to Andrew Carnie (2012: 58) the syntactician's definition of predicate is based on the mathematical notion of a "relation". The predicate defines the relation between the individuals being talked about and the real world - as well as among themselves. The entities (which can be abstract) participating in the relation are called arguments.

E.g. in a clause like: Agroni gjuajti topin. (“Agron threw the ball.")

There are two arguments in this clause: Agron and topin ("the ball"). The predicate is the verb gjuajti ("threw"). The predicate gjuajti ("threw") expresses a relation between the arguments, more precisely, the predicate indicates that the first argument (Agron) is applying some force on the second argument (topin; "the ball").

When discussing about how many arguments a predicate takes - we take into account the elements (NP, PP, CP) that are obligatory; optional ones (adjuncts) are never counted in the list of arguments. Only obligatory elements 
are considered arguments. Thus, thematic roles are assigned only to verb arguments.

The description of the clause structure through the argument structure serves as a kind of filter. If, for example, we describe a verb as gjuaj ("throw") only in terms of the syntactic relations it creates: it takes a subject and a direct object, and on the other hand, according to the syntactic categories we say that its complements are NP, NP (NP threw NP), there is the possibility of forming clauses that are not semantically correct. For example, we can form clauses like: Tavolina gjuajti topin ("The table threw the ball"). - This clause has the structure of SVO and is realized by NP-transitive verb-NP, but is semantically incorrect. In this way we see that in order to have a well-formed clause, one should also consider the semantic constraints: the verb GJUAJ ("throw"), in addition to assigning the number of complements and determining their syntactic category, also assigns certain semantic roles to its arguments: the verb gjuaj ("throw") assigns its internal argument the role of THEME ${ }^{37}$, and then the verb along with its internal argument assign the role of AGENT/DOER $^{38}$ to the subject. Since this verb requires an agent in the role of the subject, then it is understood that the clause: Tavolina gjuajti topin ("The table threw the ball") is incorrect because TAVOLINA ("the table"), having the feature (-HUMAN and -LIVING BEINGS), cannot perform or initiate deliberate actions, thus cannot be AGENT.

\section{Conclusion}

Following the research, we have come to the following conclusions:

- The structure of the clause is determined by the verb which functions as valency carrier.

- The verb assigns the number, type, and syntactic category of complements.

- In the analyzed corpus, the most typical clause structures with bivalent verbs are:

Structure

1. $\mathrm{S}-\mathrm{V}-\mathrm{O}^{\mathrm{d}}$ :

2. $\mathrm{S}-\mathrm{V}-\mathrm{Oi}$ :

\section{Example}

Dashi i moçëm e tundi kokën.

("The old ram shook its head.")

("A hungry wolf rushed into the barn of the poor man.")

\footnotetext{
${ }^{37}$ Entities that undergo actions or are moved, experienced, or perceived are called themes. (Carnie, op.cit: p. 231).

${ }^{38}$ The initiator or doer of an action is called the agent. (Carnie, ibid. p. 229).

Trakya Üniversitesi Edebiyat Fakültesi Dergisi,

Cilt: 10 Sayl: 19, Ocak 2020, s. 226-241
} 
3. $\mathrm{S}-\mathrm{V}-\mathrm{PP}$ :

Njerëzit merren me gjithfarë punësh.

("People deal with all kinds of work.")

4. S-V - Subject predicative complement: Shtëpitë janë njëkatëshe.

("The houses are one-story.")

5. $\mathrm{S}-\mathrm{V}-$ obligatory adverbial:

Ne jetojmë në Gjakovë.

("We live in Gjakova")

Structures 1 and 4 were the most frequent in the analyzed corpus.

- The description of clause structures according to functional criterion gives a more concise overview of the most typical structures with bivalent verbs.

- The above structures, described according to syntactic functions ( $\mathrm{S}-\mathrm{V}-\mathrm{O}$ etc.) are realized by different syntactic categories. In some cases, the verb directly assigns the syntactic category of complements, as is the case of transitive verbs, whereas in other cases, even though the verb does not determine the form of the complement, the assigned complement is part of the verb valency, as is the case of prepositional phrases, adverbial phrases, etc.

- The description of clause structures according to syntactic categories gives more details about certain patterns, but on the other hand, the number of patterns increases significantly.

- The verb, in the role of the predicate, also assigns semantic roles to its arguments, thus ensuring that the clauses are semantically correct. The semantics of the verb selects certain arguments and excludes other arguments that are not in line with the semantics (semantic constraints) of the verb in the predicate role.

\section{REFERENCES}

Allerton, D.J., Valency and the English verb, Academic Press, London, 1982.

ASHSH, Gramatika e gjuhës shqipe I dhe II, IGJL, Tiranë, 2002.

Biber, Douglas, et al., Longman Grammar of Spoken and Written English, Pearson Education Limited, Harlow, 1999.

Biber, Douglas, et al., Longman Student Grammar of Spoken and Written Englisht, Pearson Education Limited, Harlow, 2002.

Buchholz, Oda, Fiedler Wielfried, Albanische Grammatik, Verlag Enzyklopädie, Leipzig, 1987.

Carnie, Andrew, Syntax: A Generative Introduction, Blackwell Publishing, 2012.

Dhima, Thoma., 'Mbi klasifikimin e foljeve sipas valencës'. In: Gjuha shqipe 1-2. IAP (67-74), Prishtinë, 2002. 
Engel, Ulrich, Schumacher, H., Kleines Valenzlekion deutscher Verben.: Narr, Tübingen, 1976.

Engel, Ulrich, Deutsche Grammatik. München: IUDICIUM / Groos, 2004/ 1994.

Faulhaber, Susan, Verb Valency Patterns - A Challenge for Semantics-Based Accounts, De Gruyter, Berlin, 2011.

Fehmiu, Bekim, Shkëlqim dhe tmerr. Koha, Prishtinë, 2016.

Fillmore, Charles, 'The case for case', in: E. Bach and R.T. Harms (eds.) Universals in linguistic theory, Holt, Rinehart and Winston, New York, 1968, pp. 1-88.

Fischer Klaus, German - English Verb Valency. Gunter Narr Verlang Tübigen, 1997.

Floqi Spiro, 'Rreth modeleve të fjalisë në shqipen e sotme letrare'. Në: Studime Filologjike 4. ASHRPSH, Tiranë, 1978, pp. 25- 51.

Helbig, Gerhard, Probleme der Valenz- und Kasustheorie. Max Niemeyer, Tübingen, 1992.

Helbig, Gerhard, Schenkel, Wolgang, Wörterbuch zur Valenz und Distribution deutscher Verben. VEB Bibliographisches Institut, Leipzig, 1975.

Herbst, Thomas, et al., A Valency Dictionary of English. Mouton de Gruyter (formerly Mouton, The Hague), Division of Walter de Gruyter GmbH \& Co. KG, Berlin, 2004.

Huddleston Rodney, Pullum Geoffrey, The Cambridge Grammar of the English Language, CUP, Cambridge, 2002.

Johnson, Keith; Johnson Helen, Enciclopedic Dictionary of Applied Linguistics: A Handbook for Langugae Teaching, Blackwell Publishing Ltd, Oxford, 1999.

Koleci Flora, Turano Giussepina, Hyrje në sintaksën gjenerative të shqipes, SHBLU, Tiranë, 2011.

Quirk, Randolph, et al., A Comprehensive Grammar of the English Language: Longman, London, 1985.

Reichardt Renate, Valency Sentence Patterns and Meaning Interpretation, University of Birmingham, 2013.

Rrahmani, Zejnullah, Pesë vakte. Faik Konica, Prishtinë, 2013.

Storrer, Angelika, 'Ergänzungen und Angaben' in Ágel, V., Eichinger, H.-W., Eroms, P.H., Heringer, H.J., Lobin, H. (eds) Dependenz und Valenz / Dependency and Valency Volume 1, pp 764-780. Berlin: de Gruyter, 2003.

Tesnière Lucien, Eléments de Syntaxe Structurale, Klincksieck, Paris, 1959. 